\title{
The significance of understanding psychosexual development and sexuality education for Vietnamese adolescents
}

\author{
Lan, Nguyen Thi \\ De La Salle University, Philippines (maryxinvang@gmail.com)
}

Huong, Nguyen Huy

De La Salle University, Philippines (antonnguyenhuyhuongsp@gmail.com)

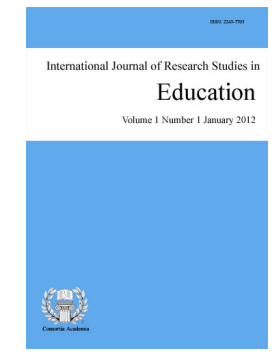

ISSN: $2243-7703$ Online ISSN: 2243-7711

OPEN ACCESS

Received: 25 October 2021

Revised: 28 October 2021

Available Online: 1 November 2021

DOI: $10.5861 /$ ijrse.2021.a128

Accepted: 1 November 2021

\section{Abstract}

The psychosexual development and sexuality of human is remarkable and important aspects. It is existing throughout the life of each person. Therefore, any ages also have the right to learn, know and understand about psychosexual development and sexuality in order to live relevantly with each phase of person and avoid unpredictable things that might happen in life, which relate to sexuality. Perhaps, the adolescence phase is one that needs more attention and education on the subject of psychosexual development and sexuality education because this is a complicated and sensitive phase. There are many countries in the world that focus on sexuality education, while there are still too many countries, sexuality education is a strange matter. Vietnam is a typical country. Up to now, sexual education seems to be a new concept in Vietnamese society. There is not yet a formal sexuality education program in the school. Most teachers, parents, and students are severely lacking in psychosexual development and sexuality knowledge. Therefore, this topic provides essential information to help Vietnamese people to raise awareness and the importance of understanding psychosexuality in general and adolescent sexuality in particular through using the psychosexual development theory of Freud and related conceptions to describe and analyze psychosexual development and sexuality, which is focusing on adolescence (10 to 19 years old). Especially, this topic will be helpful and meaningful for researchers and their congregations in their missions and ministries. Since their main charism is to educate the youth and help single moms, who have unintended pregnancies.

Keywords: understanding, psychosexual development, sexuality, adolescence, sexuality education 


\section{The significance of understanding psychosexual development and sexuality education for Vietnamese adolescents}

\section{Introduction}

According to the World Health Organization, Vietnam is one of the three countries with the largest number of abortions. About 300000 abortions are documented each year in Vietnam, $60 \%-70 \%$ of which are of people aged 15-19. These numbers are increasing each year (Ngoc Vy, 2021). Also, according to a report by the Ministry of Public Security, an average of 1,500-1,600 cases of child abuse are handled and investigated each year, of which more than $82 \%$ are sexual abuse (PV, 2019). The victims of sexual abuse are children and adolescents. There can be many causes leading to this situation, but the most important and common cause is that the children have not been adequately and effectively educated about psychosexuality and sexuality (Bao Cao Nghien Cuu, 2016).

In Vietnam and many developing countries, sexuality is still considered taboo, so people prefer not to discuss it publicly. As a result, the importance of sexuality education has always been deliberately neglected. In recent years, there has been some effort from educators to change the mindset of society on sexuality education. People, especially younger generations have begun to pay attention to their reproductive and sexual health and take action to protect themselves against the risks from sexual activities. However, according to the study of Le Thi Hien (2018), currently, formal sexuality education in school mostly does not exist; if it exists, then mostly found to be inadequate. Adolescents get little opportunity to discuss their sexuality-related issues. Lacking of proper sexual education, knowledge about sexuality, and life skills are the main reason to lead to unprotected sex, unintended pregnancy, and sexually transmitted diseases (Leung et al., 2019). This adversely affects the health and ability of adolescent learning.

Adolescence is the age with many strong changes both physically and mentally, especially psychosexual changes. At this age, children are subject to a lot of pressure and conflict (Sigfusdottir et al., 2017). Most adolescents age is always wondering, disturbed about their self-image, some of them fall into a state of anxiety, confusion, disorientation. Thus, families and schools have to take responsibility for teaching children about knowledge of psychosexual development and sexuality to help them overcome this difficult period (Ngoc Oanh, 2006).

The problem in Vietnam is not all parents and teachers have a complete and scientific understanding of psychosexual development and sexuality. If they are knowledgeable, it is not easy for them to raise this issue with their children. On the other hand, in today's schools, psychology and sexuality education is not considered a subject. They are only integrated into a number of subjects such as Citizen Education, Biology, Ethics, Life Skills, Life collective activities. Most of the textbooks have very little content on sexuality education. The above reasons are causes for their limited awareness of psychosexual development and sex education. They lead to many unfortunate consequences.

Recognizing the importance and necessity of today's sex education, therefore, we choose this topic to aim to raise the current Vietnamese educational situation on psychology, psychosexuality, and sexuality in adolescents; find out the causes and consequences of avoiding this education by using the psychosexual development theory of Freud and related conceptions to describe psychosexual development, and sexuality, focusing on adolescence, which belongs from 10 to 19 years old. Then, it is the applying and giving suggestions or recommendations for school, family, church, and society in education of psychosexual development and sexuality in adolescence to change their thinking in a positive way.

Hopefully, this topic is essential to help Vietnamese people and those who are concerned about it raise 
Significance of understanding psychosexual development and sexuality education for Vietnamese adolescents

awareness and the importance of understanding psychology and sexuality education on adolescence, based on psychosexual development Freud's theories. Moreover, as a religious person, studying this topic is a good chance to accumulate knowledge, experiences, and motivation for us on our future mission in Vietnam. Since their main charism of her congregation is to educate the youth and help single moms, who have unintended pregnancies.

\section{Methodology}

In carrying out and developing the research topic: the See, Judge, and Act method is used. The SEE aspect includes the status of education, causes, and consequences of lack of psychosexual and sexual knowledge on adolescents in Vietnam. This part will deliver general views on the status of sexual education in Vietnam to see that why this topic is needed and significant. In the JUDGE aspect, the researcher will analyze the significance and role of understanding psychosexual development and sexual education on adolescents by basing on the psychosexual development theory of Freud and related conceptions. And the ACT aspect, the application or appropriation of the analysis to Vietnamese sexuality education. Some recommendations or suggestions will be given for the Sexual Education of Vietnamese adolescents to contribute to improving general education.

\section{Discussion}

\subsection{Status of education on psychosexual development and sexuality in Vietnam}

In many countries, sexuality education is a part of the official curriculum, but in Vietnam, it is not considered an important school subject (Thu Ha, 2018). According to the Nhan Dan's News, in the growing social conditions, the student ages also develop strong psychophysiology, puberty earlier than before. The school is considered to be a reliable place to bring useful knowledge about gender and sexuality to students. But it seems that the contents of sexuality education in both teaching and learning are still formalistic, not close to reality. That has caused students to have a vague understanding of sexuality - an indispensable knowledge for them to confidently enter life (Ngoc Du, 2016).

According to Dr. Phuong Anh, at present, the issue of sexual health education in schools has not been strengthened due to some notions of "drawing the way for deer to run", so many schools and teachers are afraid of contacting about this issue. we have to discern that "Sex education is not" drawing the way for the deer to run "but it is about helping young people to avoid bad things that might happen in life. As Sao Mai (2019) asserts, it is the self-conscious and avoidant mentality that makes children will not have sufficient knowledge about sexual health, which will gradually increase the number of abortions.

In fact, the implementation of sexuality education in Vietnam was initially organized but was not sufficient and effective. The sexuality education program is integrated into other subjects such as 'Health' or 'Biology'. It causes overlaps in management and does not create specialization and efficiency in imparting knowledge to children. In the mid-2020, a group of young people founded the startup WeGrow Edu (abbreviated WE) to change the situation of sexuality education in Vietnam said that the human need to know psychosexuality and sexuality knowledge to protect themselves from threats is a legitimate need. They highlighted that eliminating obstacles, bringing sexuality education into schools are the most effective ways to solve the root of current youth sexuality and reproductive health problems. To achieve this, it is more than necessary to involve the authorities, the family, the school, and the whole society. Only that, we can create a stable society, good future generations for the country (Tu Anh, 2020).

Currently, in Vietnam, there is no formal program in Vietnam to teach psychosexuality and sexuality in any school. At school is like that, at home, parents do not care about this issue, partly because they are focusing on the economy, partly because they do not have enough sexual knowledge and shy to talk about sexuality, mainly students search for this knowledge by themselves through the internet or books. 


\subsection{Causes and consequences of lack of psychosexual and sexual knowledge on adolescent}

Causes - According to the result of a survey on 800 students from VOV.VN (2018) - By the end of grade 9 , about $10 \%$ of students have had sex, $39 \%$ by the end of grade 12 and $10 \%$ of high school students have had sex with 3 or more people. Even though this is a small group survey with 800, it is enough for us to startle. What are the causes to lead to this consequence? Psychologist Vu Thu Ha said the main reason is the lack of education on gender and sexuality.

According to another recent survey by the General Department of Family Planning Population (2019): only $19 \%$ of pupils and students receive knowledge about reproductive health, sexual health in schools, $14 \%$ from medical staff. $15 \%$ from mother and $3 \%$ from father. The remaining $49 \%$ do their own research through the Internet, through word-of-mouth experience, or "blind" information (Tong Cuc Thong Ke, 2019). Through this survey, we can find out the reasons, why do they lack sexual knowledge?

There are many reasons to lead lacking sexual knowledge. First, they have not equipped enough sexual knowledge even from in their family. They are not taught much from parents, who are closest to them. Parents have frequently reported feeling uncomfortable or embarrassed when they talk about sexuality to their children. Providing sex education to children was difficult for Vietnamese parents because they do not have enough sexual knowledge do not know how to teach or guide them on sex-related content. Parents' levels of sex-related knowledge and sexuality have very strong influences on the formation of sound sex-related values in children. However, parents do not have accurate knowledge and desirable attitudes toward participating in their children's sex education at home (Lee \& Kim, 2017).

Second, most of the schools in our country still shy away from teaching sexuality (Sen, 2019). Although it is necessary and urgent, the education of sex in schools today is still perfunctory and is considered to be behind the development of children. There has not been a complete sexuality education program in the educational system until now. It's just an activity integrated into Citizen Education, Biology, or Life Skills programs.

Furthermore, it lacks trained sex-ed teachers in Vietnam. According to Deputy Director-General of the General Department of Population and Family Planning (Ministry of Health) Nguyen Thi Ngoc Lan, although all levels and sectors have made great efforts in propaganda, education and health care, sexual health for adolescents and young people. Nevertheless, at present, the knowledge and skills of adolescents and young people are still limited. Education on reproductive and sexual health is not widely accessible. The provision of friendly information and services on reproductive and sexual health has not met the diverse needs of adolescents and young people (Minh Hue, 2020).

Third, the government and society have not paid much attention to the education of students in this field. In another hand, Misperceptions about sexuality education, love education. There are many people who believe that sex education is sex education, that is drawing the way for children to run. They are afraid that if they teach the children about sexuality, they will be curious and doing. Moreover, Vietnamese adolescents and youth today have had changes in customs and culture, such as getting married at a later age and increasing sex before marriage.

Besides that, Vietnam does not have a team of staff, teachers with scientific knowledge in the field of sexuality to do educational work for the youth. Additionally, scientific documents, textbooks, books, and articles researching deeply on this issue are not extensive yet. Contrarily, the rampant black and depraved Web are inundating. They make it difficult for the youth to select information relevant to each development stage that they themselves need to learn about (Thu Hien, 2018). They have uncontrolled access to information on social networks and movies. Those reasons and many other reasons else of life make adolescents lack sexual knowledge. In sum, because they are lacking concerning from parents, school, and society on this field.

Consequences - The lack of knowing psychosexual development, sexuality education, and equipping 
Significance of understanding psychosexual development and sexuality education for Vietnamese adolescents

adolescents with knowledge about relationships will cause many problems in present as well as later life.

First, Young people today are at risk of early sex, unsafe sex; susceptible to sexual abuse leading to more susceptibility to sexually transmitted diseases including HIV/ AIDS; Unintended pregnancy, unsafe abortion. This action easily leads to health consequences such as infection, bleeding, infertility (Shrestha, 2019). The most ominous thing about having sex at the age of students is that most of them have sex in an unready or passive condition. The girls agreed to "have sex" just because their boyfriend was happy or influenced by the environment, so then they often fell into fear and insecurity.

Second, when adolescents had a pregnancy, it heavily affects physical and psychological development as well as intellectual development in the future. More importantly, the psychological shock after abortion, because most of them go for abortions. Therefore, many young people have a disdain for tormenting and looking down on themselves, or arising a feeling of hatred for men, even in cases of suicide to liberate (Ha Quyen, 2015).

Third, in addition to the consequences for yourself, early sex also has economic and social consequences: Limited ability to study or drop out of school leads to reduced chances of finding good jobs or giving up motherhood, sometimes being pessimistic to commit suicide, becoming a prostitute ... (Van Khanh, 2019). According to studies in Vietnam, the rate of adolescent abortion is increasing. There are cases that after being distributed online pictures or clips, they are psychological trauma that leads to suicidal behavior. Currently, each year the abortion rate in Vietnam is about 300,000 cases, of which about 60-70\% of adolescent age. This number is increasing, of which Vietnam ranks 5th in the world, leading in Southeast Asia in terms of abortion. Dr. Le Thi Kim Dung concluded this is the result of young people not understanding the concept of love, sexuality, and the dangers when deciding to "cross the fence" without appropriate preventive measures (Hong Minh, 2018).

\subsection{Freud's theory and conceptions relate to topic}

Psychosexual development of Freud and its implication to adolescent sexuality education - From 19 centuries, there are many scholars concerned and studied Psychosexual Development such as Albert Moll (1862-1939), Sigmund Freud (1856-1939), Carl Gustav Jung (1875-1961), William Stern (1871-1938), and Charlotte Bühler (1893-1974). However, the historiography to date has mainly centered on Freud, who is perceived as the one who introduced the notion of sexuality being central to, and normal in, infancy and childhood. Despite the recognition that Freud's work was neither revolutionary nor unique, alternative approaches to child sexuality, such as those by Moll, Jung, Stern, and Bühler, have largely been neglected. This is perhaps because Freud's contribution is perceived as the most influential (Sauerteig, 2012). Therefore. This topic is also mostly based on the psychosexual development of Freud to describe, dissect, and apply to education on adolescent sexuality in Vietnam.

According to Freud (1920), everyone, including children is basically hedonistic. They always have the tendency to seek pleasure by gratifying the Id's desires. In another work of Freud (1905) show that normally each person moves through different developmental stages, the location of the libido, and hence sources of pleasure are also changing. He additionally that environmental factors and parental experiences during childhood influence an individual's personality during adulthood. If the child's needs were met in full or at least adequately by healthy nurturing, they could advance into adulthood with a healthy personality. As to be mentioned by Saul McLeod, (2019) There are five stages of Freud's psychosexual development theory that are broken up as follows. Each stage contains an age range, stage name, an erogenous body part, and the associated consequence of fixation at that stage of development: Oral Stage (Birth to 1 year) -the libido is centered in a baby's mouth. Anal Stage (1 to 3 years) -The libido now becomes focused on the anus, and the child derives great pleasure from defecating. Phallic Stage (3 to 6 years) -Sensitivity now becomes concentrated in the genitals and masturbation (in both sexes) becomes a new source of pleasure. Latency Stage (6 years to puberty) -The libido is dormant. sexual energy can be sublimated towards school work, hobbies, and friendships. Genital Stage (puberty to adult) -It is a time of adolescent sexual experimentation, the successful resolution of which is settling down in a loving 
one-to-one relationship with another person. This paper also focuses on this stage (10-19 years old).

In Sigmund Freud's Psychosexual Theory, he believes that the behavior and development of a person are influenced by the interaction between the conscious and unconscious aspects of that person's mind. In that, Freud portrays adolescence as being fraught with an internal struggle. According to him, during this stage of psychosexual development, the "genital" phase; the child is inundated with instinctual impulses which disrupt the balance between the ego and id. Discovering psychosexual development of adolescence have us understand them better, then we can teach them how to avoid dangerous temptation around their lives and eliminates the unfortunate consequences, which relate to sexuality at this age. Sarah E. Lantz; Sagarika Ray (2020) in the article "Freud Developmental Theory" drew out the conclusion to Freud's theories, Freud's developmental theories on psychosexual development were among the first attempts to bring psychology under the same scientific structure and methodology of medicine and biology. Freud was able to identify various stages, and their associated consequences should a child experience trauma during that developmental period. The theory was based on a child being born "polymorphously perverse." This essentially means that a child is born a tabula rasa regarding which part of the body they can derive sexual pleasure from. Freud's developmental theory focused on two pivotal elements of human nature, "sex" and "aggression." Socialization during the child's upbringing was what drove the development of the child's libido.

As DeLamater and Friedrich (2002) in "Human sexual development" shown that the process of achieving sexual maturity begins at conception and ends at death, which brings a change in an individual, every moment. Development of sexuality starts as early as in intrauterine life following conception and continues through infancy, childhood, adolescence, adulthood till death. Therefore, we can confirm that sexuality is an important part of our persons. No matter who you are, how old you are, what your gender is, sexuality always exists in you. Recognizing this thing, we need to determine that sexuality education for each person is very important because sexuality always exists in us, from we are born to we die. Sexuality education is throughout the processing of life, especially, in the adolescent stage, this matter is manifested clearly. It is needed to be more considered at this stage. According to Freud's theory, the environmental factor and parental experiences during childhood influence an individual's personality during adulthood. Therefore, educators as parents, teachers, caregivers have to have the responsibility to educate related matters to sexuality for them adequately.

\subsection{Related conceptions}

Adolescence - According to The World Health Organization (WHO, 2006) defines an adolescent as any person between ages 10 and 19. Adolescence is sometimes divided into early (10-14), middle (15-17) and late periods (18-19). These periods roughly correspond with the phases in physical, social and psychological development in the transition from childhood to adulthood. Allen et al. (2019) supposed that this is the period of transition between childhood and adulthood. It includes some big changes - to the body, and to the way a young person relates to the world. There are many changes on physical, sexual, cognitive, social, and emotional that happen during this time. They can bring anticipation and anxiety for both children and their families. Understanding what to expect at different stages can promote healthy development throughout adolescence and into early adulthood.

Sexuality education - According to Cora C. Breuner et al. (2016), Sexuality education is defined as teaching about human sexuality, including intimate relationships, human sexual anatomy, sexual reproduction, sexually transmitted infections, sexual activity, sexual orientation, gender identity, abstinence, contraception, and reproductive rights and responsibilities. Sex education is the acquisition of knowledge that deals with human sexuality. Sexuality education is the instruction of issues relating to human sexuality, which it is a process whereby information is given or imparted to a group of young ones and which takes into account the development, growth, the anatomy and physiology of the human reproductive system and changes that occur from youth all through stages of adulthood. In Mary Ogechi Esere (2008) words, sex education involves providing children with knowledge and concept that will enable them make informed and responsible decisions

24 Consortia Academia Publishing (A partner of Network of Professional Researchers and Educators) 
Significance of understanding psychosexual development and sexuality education for Vietnamese adolescents

about sexual behaviors at all stages of their lives. Sexuality is an important aspect of the life of a human being and almost all people, including children, want to know about it. But it should be age appropriate and available to everyone through a variety of forms. Of course, common avenues for sex education are parents or caregivers, formal school programs, and public health campaigns.

Development of sexuality in an adolescent - As mentioned above, Sigmund Freud had proposed his theory of psychosexual development, where he described - oral phase, anal phase, phallic phase, latency phase, and genital phase as the landmark steps of psychosexual development. During these phases, different body parts behave as most erotogenic, and the individual attempts to explore or stimulate these erotogenic zones in order to get gratification. According to him, during early adolescence, an individual enters the genital phase from the latency phase. The sexuality is quiescent during the latency phase. Then, throughout the next adolescence, the genital phase is maintained and sexuality becomes active during the genital phase.

Ott M. (2010) in the article "Examining the development and sexual behavior of adolescent males" believes that during adolescence, an individual's need for intimacy and lovemaking with the opposite gender increases. They explore different appropriate ways to express love and intimacy and begin to show a general interest in sexual topics. Youth may try to satisfy their curiosity by reading information about sex and viewing images with sexual content. They can readily find these images at the library, in an older sibling's biology textbook, watching certain television programs, viewing adult magazines, or searching on the Internet. It is normal for youth to want to avoid the embarrassment of being discovered doing any of these things so they may attempt to deny or conceal what they are doing. During early adolescence, most teens become curious about sex, but any sexual behavior is usually limited to masturbation. However, by middle to late adolescence, many teens begin to experiment with various sexual behaviors via masturbation, partners, or both. Angela Oswalt Morelli adds more, both guys and girls may start to experiment with sexual arousal through flirting, hugging, and playfully hitting or tickling other youth they are romantically interested in. They may also start kissing or "making out" with other teens. Adolescents form new peer relationships and become increasingly interested in romantic and potentially intimate sexual partners. In addition, adolescents crave privacy in a variety of realms, including matters related to their bodies and their relationships with peers. Indeed, adolescence is the period during which an individual's thought perception, as well as response, gets colored sexually. This is the age to explore and understand sexuality. Sexual curiosity in adolescence led to exposure to pornography, indulgence in sexual activities, and also increases the vulnerability for sexual abuse (Kar et al., 2015).

In this period, adolescents face great challenges. Many critical biological, as well as psychological changes, occur during this phase. If adolescents are not prepared enough to cope with self- changes, they often feel stressed. The onset of menstruation in girls, change in voice in boys, development of secondary sexual characteristics, and psychological changes are often perceived as challenges. Therefore, Family and society's attitude, as well as a cultural influence in this period plays a major role in deciding the adolescent's sexual behavior after puberty (Kar et al., 2015). It is important for caregivers to be prepared to discuss all aspects of sexuality (i.e., the physical, cognitive, emotional, social, and moral aspects of sexuality) so that they can best assist their teens to make wise and thoughtful decisions. We need to equip them with necessary sexual knowledge because a lack of proper sex education often leads to unprotected sex, unintended pregnancy, and sexually transmitted diseases. As Kumar et al. (2017) considered, there are multiple reasons make adolescents are exposed to unprotected sex. Nevertheless, lack of awareness and improper sex education is an important reason for unprotected sex in adolescents.

The role of sexual education for adolescents - Sexuality education is a part of education in general and ethical education in particular. However, sexuality education has its own meaning and purpose. It focuses on the individual gender and sexuality aspect to help the young generation to develop and strengthen the ability, to have a healthy attitude, and understand about sexuality. Then they can make conscious, satisfying, healthy and respectful choices regarding relationships, sexuality and emotional and physical health. Sexuality education does not encourage children and young people to have sex (Grose et al., 2014). Therefore, sexuality education is one 
of the issues that the society, school and family really need to pay attention to. If sexual education is conducted with quality and suitable each age, it will have the following impacts

First, sexuality education plays an important role in forming a child's personality, it helps people develop a more harmonious personality. Since sexuality education is an important part of the comprehensive development of human personality. Sexuality education aims to foster young generation knowledge about gender and sexuality, forms in them attitudinal and polite communication skills, and civilization in relations with the opposite sex in social activities and life (Ngoc Oanh, 2008, pp. 157-158). Through learning of sexuality children to be aware of their body and, reduce curiosity, fear or problems of psycho-physiological changes in puberty. They help them to control their psychology and sexuality. So that it is minimizing unexpected events from the lack of understanding in adolescents.

Second, sexuality education in adolescents becomes more and more urgent. When students are equipped with the necessary knowledge about sexuality education, they will prepare their thoughts to become more successful and to think more accurately. When they are equipped with comprehensive knowledge and understanding about their body and psychosexual development to prevent as well as solve problems can happen. At least, with basic knowledge about sexuality, they will minimize the undesirable situation happening to them.

Third, Sexuality education has positive effects, including increasing young people's knowledge and improving their attitudes related to sexual and reproductive health and behaviors. As it provides the knowledge and skills needed to make safer and healthier choices; reduces risky behaviors particularly among those who are sexually active; and reduces vulnerability to HIV and other risks associated with gender inequality (UNESCO, 2018). Sexuality education though in or out of schools, it helps to reduce sexual activity, sexual risk-taking behavior and reducing rates of unintended pregnancy sexually transmitted diseases. Moreover, in addition to the sense of self-worth, the understanding of psychosexual development and sexuality will make children respect their opposite sex friends, manage their emotions and understand well about love between couples.

In brief, the primary goal of sexuality education is that children and young people are equipped with the knowledge, skills and values to make responsible choices about their sexual and social relationships (UNESCO, 2009).

\section{General recommendations for adolescent sexual education in Vietnam}

It is very true to Vietnamese education when Balter et al. (2016) say that despite it being an increasing amount of sexual research, but health and education professionals, and parents know little about normal sexual development. So, to safeguard and support the sexual development of adolescents, it is needed for parents, teachers, and other professionals working with children and adolescents. For, sexual education is a lifelong process that begins at birth. As Ashcraft \& Murray, (2017) mentioned in their study that parents/caregivers, family, peers, partners, schools, religious organizations, and the media influence the sexual development of children at all stages of life. All people, especially adolescents have the right to accurate information and ageand developmentally appropriate education about sexuality. Raising awareness of this issue for adolescents requires comprehensive coordination from family, school, society, and State.

The State - The state should pay attention to invest in programs to raise awareness and understanding for parents about the psycho-physiological features of the (10-19-years-old) adolescents, the risks related to psychosexuality, sexuality, and reproductive health in this age group, as well as equipping parents with communication skills on puberty and sexuality. So that families can effectively exercise health care for children, including protecting children from risky behaviors related to having sex before marriage and getting pregnant or having a teen. It is possible to consider developing and improving the effectiveness of propaganda measures on modern media so that parents can easily access them, such as: Setting up a thematic page on exercising children's rights online, propagating through social networks. The State also needs strict measures and sanctions in the management of social order and security, for example, protecting children from the phenomenon of manipulation, 
Significance of understanding psychosexual development and sexuality education for Vietnamese adolescents

seducing children into social evils, and child abuse. This is also the state's support to families in exercising their right to protect children from environmental threats outside of society.

The school - One of today's social problems in Vietnam is that adolescents have sex without adequate knowledge about reproductive health care, especially sexually transmitted diseases. That has disastrous consequences for society and affects their own future. To overcome this situation, there is no other way better than bring sexuality education into the most important environment of adolescent children in school as soon as possible. It is necessary sexual education programs to be implanted since early ages in schools (Ballester \& Gil 2006). This is considered the effective and key way to improve children's understanding of psychosexual development and sexuality. And it is a necessary condition to reduce sexual consequences for them and the whole society from the lack of sexual education knowledge (Tư Van Ho Tro, 2017). Furthermore, it is necessary to promote more collaborative activities with families in providing knowledge as well as skills about sexual and reproductive health for students aged adolescents. Currently, the coordination between the school and the family is mainly focused on learning and training ethics for students, but not interested in this topic.

It is important for schools to propose to the education sector to enhance the life skills subjects/hours for students, especially teenage students, about self-protection skills, communication skills, decision-making skills, and skills related to adolescent sexual health. In addition, the school also needs to strengthen extracurricular activities to propagate sexual health and self-protection skills from reproductive health risks and risks of sexual harassment and abuse.

Thinking that school should have some activities to improve the quality of sexuality education for adolescent students such as:

$>\quad$ Raising awareness about sexuality education for parents, students, administrators, teachers, and other people by organizing, mobilizing, and exploring resources that relate to psychosexual development and sexuality education, building bookcases about it. Encouraging teachers and students to do their own research and writing harvest reports, discussing, and examining to improve their understanding of sexual knowledge. At the same time, invite experts on psychology and medical education to exchange, discuss and talk about age physiology, psychosexual development, and sexuality.

$>\quad$ Regularly fostering to improve the capacity of sexuality education for school officials and teachers. Concretely, the school must plan for the training - professional training of sexuality education activities for teachers according to each semester, school year. It is necessary to choose the method and form of training organization to suit the fostering subjects and the conditions of the school. it should be to send key teachers to participate in courses on sexuality education training so that they have the basic knowledge and skills necessary for this activity; then they will instruct other teachers.

$>\quad$ Guiding teachers to integrate sexuality education contents through teaching the dominant subjects and extracurricular activities by increasing the use of active teaching methods and increasing the time spent on these contents in biology, physical exercises, civic education subjects

$>\quad$ Promoting the coordination between the school - Family - Society in sexuality education activities for students because participating in the education of students is not only teachers but also many educators inside and outside the school.

$>$ Especially, the Ministry of Education and Training needs to decide early and immediately apply sexual psychology as a regular subject in the school. Moreover, according to a recent survey by the Ministry of Education and Training at a number of junior high schools, high schools, and universities in Hanoi, Hai Duong, most students have difficulty with mental, psychosexual, physiological problems (in which junior and high school is $95.33 \%$, the university is $85.92 \%$ ). In particular, at the age of high school students, the frequency of problems and need to share is the highest at $80.17 \%$; having $82.31 \%$ 
of students are questioned to wish schools and educational institutions to have their own private psychological counseling rooms for their convenience. Most of the students want in the school to have a professional psychologist trained in school, with expertise in school psychology to help them share their difficulties and problems (Quynh Nguyen, 2017). Hopefully, this wish will be done soon.

$>\quad$ The school should organize diverse educational activities, which are suitable for the ages such as opening seminars, extracurricular activities on children's psychosexual development, friendship among students, effective learning methods, or organizing cultural and sports movements.

The Parents - As parents often play as role models and are most aware of their children's specific development, sex education has been shown to be very effective when parents and children discuss sex-related issues together (Somers \& Anagurthi, 2013). Therefore, parents need to learn about the psychosexual development and sexuality of Children to raise awareness and attitudes towards sexuality education, in order to bring the best education to their children. They should not hide or take a negative view of sexual issues because it affects their perception and leads to panic fear when children are in the age of physical change and spirit. It is very helpful when parents create a family atmosphere filled with love so that they can create their trust and be able to have a normal, intimate conversation about sexuality. The spirit of openness and non-judgment when children share and discuss sexual issues, especially adolescent sensitive issues, is what parents should do. In addition, parents also need to respect and listen to children when they share their personal opinions and facilitate or encourage children to raise their ideas.

Adolescents themselves - Psychologist Thu Ha (2018) gave some pieces of advice that: In order to have feelings when falling in love does not distract from learning and other social activities, children must have knowledge of adolescent sexuality, human psychosexual development, and reproductive health. Thus, adolescent themselves have to learn by any way to improve sexuality knowledge. Second, you must be able to supervise and manage the limits of those emotion. Third, they have to listen to teachers, parents, and those who are take care them. In addition, they should have experiences in community life and put life's goals to reach to be not distracted by emotions.

\section{Conclusion}

Handan Gunes and Balaban (2012) said sexual education should not be regarded as a taboo anymore and should not be neglected. Sexuality is a part of our lives and should be regarded as our other needs such as sheltering and sleeping. Therefore, understanding the sexuality development and sexuality of adolescent is of utmost importance. Understanding adolescent sexuality will help parents, teachers, and caregivers to understand the difficulties of their children better and will help them to guide their children in the crossroads of adolescence. In Vietnam, until now, sexuality education has always been considered a sensitive topic, has not been widely implemented and popularized in schools, many parents still feel "shy" when talking to their children. However, sexual education for students is a meaningful work for students to know to protect themselves against the dangers that can be encountered anytime, anywhere. Like any other aspects of education, sexual education always invites parents, teachers, and caregivers to find a suitable way for their children. To do educating children on sexuality in a transparent, appropriate and effective way, it requires a subtle, sensitive, progressive and comprehensive approach. So that, they can equip for themselves the best knowledge to go in life.

\section{References}

Allen, B., \& Waterman, H. (2019). Stages of Adolescence. https://www.healthychildren.org/English/ages-stages/teen/Pages/Stages-of-Adolescence.aspx

Angela, O. M. (n.d.). An introduction to adolescent development (12-24). Retrieved Dec. 28, 2020, from https://www.gracepointwellness.org/1310-child-development-theory-adolescence-12-24/article/41149-a $\underline{\text { n-introduction-to-adolescent-development }}$ 
Significance of understanding psychosexual development and sexuality education for Vietnamese adolescents

Ashcraft, A. M., \& Murray, P. J. (2017). Talking to parents about adolescent sexuality. Pediatric clinics of North America, 64(2), 305-320. https://doi.org/10.1016/j.pcl.2016.11.002

Ballester Arnal, R., \& Llario, G. (2006). Sexuality in children 9-14 years old [La sexualidad en niños de 9 a 14 años]. Psicothema, 18(1), 25-30. National Center for Biotechnology Information. https://pubmed.ncbi.nlm.nih.gov/17296005/

Balter, A. S., van Rhijn, T., \& Davies, A. (2016). The development of sexuality in childhood in early learning settings: An exploration of early childhood educators' perceptions. The Canadian Journal of Human Sexuality, 25(1), 30-40. http://dx.doi.org/10.3138/cjhs.251-A3

Bao Cao Nghien Cuu. (2016, May 19). Sexuality education for children [Giao Duc Gioi Tinh Cho Tre Em]. https://vinaresearch.net/public/news/

Cora, C., Breuner, et al. (2016). Sexuality education for children and adolescents. American Academy of Pediatrics, 138(2). https://doi.org/10.1542/peds.2016-1348

DeLamater, J. \& William N. Friedrich (2002) Human sexual development. The Journal of Sex Research, 39(1), 10-14. https://doi.org/10.1080/00224490209552113

Esere, M. O. (2008). Effect of sex education programme on at-risk sexual behavior of school-going adolescents in Ilorin, Nigeria. African health sciences, 8(2), 120-125. https://doi.org/10.4314/njgc.v11i1.36988

Freud, S. (1920). Beyond the pleasure principle. SE, 18: 1-64. Translated and edited by James Strachey. New York -London: Norton Company. Retrieved Nov. 28,2020, from http://xenopraxis.net/readings/freud_beyondthepleasureprinciple.pdf(16/11/2020)

Freud, S. (1905). Three essays on the theory of sexuality. The standard edition of the complete psychological works of Sigmund Freud, Volume VII (1901-1905): A case of hysteria, three essays on sexuality and other works, pp. 123-246.

https://www.sas.upenn.edu/ cavitch/pdf-library/Freud_SE_Three_Essays_complete.pdf

Grose, R. G., Grabe, S., \& Kohfeldt, D. (2014). Sexual education, gender ideology, and youth sexual empowerment. The Journal of Sex Research, 51(7), 742-753. https://doi.org/10.1080/00224499.2013.809511

Ha Quyen. (2015). Heartbreaking consequences of lack of knowledge about sexuality [ Hau qua dau long vi thieu kien thuc goi tinh]. Retrieved Jan. 4, 2021 from https://zingnews.vn/hau-qua-dau-long-vi-thieu-kien-thuc-gioi-tinh-post519535.html

Handan Gunes, M., \& Balaban, M. (2012). Determination of science teacher candidates' attitudes, opinions and information requirements regarding sexuality. Procedia-Social and Behavioral Sciences, 46, 4310-4316. https://doi.org/10.1016/j.sbspro.2012.06.246

Hien, L. T. (2018). The awareness on sexuality education of parents, who have adolescent children [Nhan thuc ve giao duc gioi tinh cua nhung bac cha me co con o vi thanh nien].

https://123docz.net//document/3843331-nhan-thuc-ve-viec-giao-duc-gioi-tinh-cua-nhung-bac-cha-me-c o-con-o-do-tuoi-vi-thanh-nien.htm

Hong Minh. (2018). The surprising situation about sex in Vietnamese today [Thuc trang bat ngo ve tinh duc hoc duong o Viet Nam hien nay]. Retrieved Jan. 2, 2021, from https://zingnews.vn/thuc-trang-tinh-duc-hoc-duong-o-viet-nam-hien-tai-nhu-the-nao-post826002.html

Kar, S. K., Choudhury, A., \& Singh, A. P. (2015). Understanding normal development of adolescent sexuality: A bumpy ride. Journal of human reproductive sciences, 8(2), 70-74. https://doi.org/10.4103/0974-1208.158594

Kumar, R., Goyal, A., Singh, P., Bhardwaj, A., Mittal, A., \& Yadav, S. S. (2017). Knowledge attitude and perception of sex education among school going adolescents in Ambala District, Haryana, India: A cross-sectional study. Journal of clinical and diagnostic research: JCDR, 11(3), LC01-LC04. https://doi.org/10.7860/JCDR/2017/19290.9338

Lee, E., \& Kim, H. (2017). Development and effects of a children's sex education program for the parents of lower elementary grade students. Journal of Korean Academy of Nursing, 47(2), 222. https://doi.org/10.4040/jkan.2017.47.2.222

Leung, H., Shek, D., Leung, E., \& Shek, E. (2019). Development of contextually-relevant sexuality education: 
Lan, N. T., \& Huong, N. H.

lessons from a comprehensive review of adolescent sexuality education across cultures. International journal of environmental research and public health, 16(4), 621. https://doi.org/10.3390/ijerph16040621

Minh Hue. (2020, Sep. 25). For the healthy development of adolescents and young people [Vi su phat trien lanh manh cua vi thanh nien va thanh nien]. Retrieved Dec, 31, 2020, from https://www.baoquangbinh.vn/suc-khoe

Ngoc Du. (2016). The "hole" of sex education [ Lo hong gioa duc gioi tinh]. Journal of Nhan Dan. https://nhandan.com.vn/chuyen-de-cuoi-tuan/lo-hong-giao-duc-gioi-tinh-384035

Ngoc Oanh, Bui. (2008). Psychosexuality and sexual education [Tam ly gioi tinh va giao duc gioi tinh]. Trung Tam Vi Nguoi Mu Sao Mai, Giao Duc.

Ngoc Vy. (2021). 60-70\% of abortions are students [60-70\% cac ca pha thai la sinh viên va học sinh. Electronic Journal of Nhan Dan.

https://nhandan.vn/tin-tuc-xa-hoi/60-70-cac-ca-pha-thai-la-sinh-vien-va-hoc-sinh-643226/

Ott M. A. (2010). Examining the development and sexual behavior of adolescent males. The Journal of Adolescent Health: Official Publication of the Society for Adolescent Medicine, 46(4 Suppl), S3-S11. https://doi.org/10.1016/j.jadohealth.2010.01.017

PV. (2019, may). Child sexual abuse is a complex phenomenon [Nạn xam hai tinh duct re em dien ra phuc tap]. http://mattrantoquoc.vinhphuc.gov.vn/tintuc/pages/tin-tuc-tong-hop.aspx?ItemID=31578

Quynh, Nguyen. (2017). Sexuality education is never too late [Giao duc gioi tinh chuyen chua bao gio muon]. Journal Nhan Dan.

https://nhandan.com.vn/tin-tuc-giao-duc/giao-duc-gioi-tinh-chuyen-chua-bao-gio-muon

Sao Mai. (2019. Oct). Consequences of lack of reproductive health knowledge [ He luy cua viec thieu kien thuc sinh san]. Retrieved Jan. 3, 2021, from http://www.baodongnai.com.vn/xahoi/201907/2955087/index.htm

Sarah, E. L., \& Sagarika, R. (2020). Freud developmental theory. StatPearls Publishing LLC. https://www.ncbi.nlm.nih.gov/books/NBK430685/

Sauerteig L. D. (2012). Loss of innocence: albert moll, Sigmund Freud and the invention of childhood sexuality around 1900. Medical history, 56(2), 156-183. https://doi.org/10.1017/mdh.2011.31

Saul, McLeod. (2019). Freud's psychosexual stages of development. Retrieved Dec. 30, 2020, from https://www.simplypsychology.org/psychosexual

Sen. (2019, Mar 8). Dim light at the end of sex education tunnel. Retrieved Jan. 2, 2020 from https://e.vnexpress.net/news/life/trend/dim-light-at-the-end-of-sex-educatio

Shrestha, R. B. (2019). Premarital sexual behaviour and its impact on health among adolescents. Journal of ealth Promotion, 7(June), 43-52. https://doi.org/10.3126/jhp.v7i0.25496

Sigfusdottir, I. D., Kristjansson, A. L., Thorlindsson, T., \& Allegrante, J. P. (2017). Stress and adolescent well-being: The need for an interdisciplinary framework. Health Promotion International, 32(6), 1081-1090. https://doi.org/10.1093/heapro/daw038

Somers, C. L., \& Anagurthi, C. (2013). Parents' attitudes about adolescents' premarital sexual activity: The role of inter-parent consistency/inconsistency in sexual outcomes. Health Education Journal, 73(5), 545-553. https://doi.org/10.1177/0017896913506702

Thu Ha. (2018). Schools neglect teaching students about sex education. Retrieved Dec. 27, 2020 from http://english.vietnamnet.vn/fms/education/175113/schools-neglect-teaching-students-about-sex-educati on.html

Tong Cuc Thong Ke. (2019, Dec.19). School sex education is still superficial [Giao duc hoc duong con hoi hot]. https://thi.tuyensinh247.com/giao-duc-gioi-tinh-hoc-duong-con-hoi-hot-c33a5720.html

Tu Anh. (2020, May). Vietnamese startup, want to change the situation of sex education in Vietnam [Startup Viet muon thay doi tinh trang giao duc gioi tinh o Viet Nam]. Retrieved Jan, 2, 2021 from https://enternews.vn/startup -172963.html

Tu Van Ho Tro. (2017). Putting sex education in schools. Should it is or not? [Dua giao duc gioi tinh vao truong hoc, nen hay khong nen]. https://sites.google.com/site/giaoducdaotao123/

30 Consortia Academia Publishing (A partner of Network of Professional Researchers and Educators) 
Significance of understanding psychosexual development and sexuality education for Vietnamese adolescents

UNESCO. (2009, June). International guidelines on sexuality education: evidence informed approach to effective sex, relationships and HIV/STI education.

https://reliefweb.int/sites/reliefweb.int/files/resources/8556521DD9D4A9E64925762000240120-UNES CO-Aug2009.pdf

UNESCO. (2018, Feb. 15). Why comprehensive sexuality education is important. https://en.unesco.org/news/why-comprehensive-sexuality-education-important

Van Khanh. (2019). Adolescent worries and solutions [ Nhung dieu dang lo ngai o tuoi vi thanh nien va giai phap]. Retrieved Jan. 2, 2021, from https://stttt.bacgiang.gov.vn/chi-tiet-tin-tuc/-/asset_publisher/RcQOwn9w7wOJ/content/nhung-ieu-ang-1 o-ngai-o-tuoi-vi-thanh-nien-va-giai-phap?inheritRedirect=false

VOV.VN. (2018, Apr., 23). Vietnamese schools "afraid to teach" sexual education [Truong hoc Vietnam con ngai day giao duc gioi tinh]. https://vov.vn/tin-24h/truong-hoc-o-viet-nam-con-ngai-day-giao-duc-gioi-tinh-754226.vov

World Health Organization. (2006). orientation programmed on adolescent health for health-care providers. https://www.who.int/maternal handout.pdf 
Lan, N. T., \& Huong, N. H.

32 Consortia Academia Publishing (A partner of Network of Professional Researchers and Educators) 